\title{
The History of Madrasa Development in Indonesia
}

\author{
Fajar Syarif \\ Institut Ilmu Al-Quran (IIQ) Jakarta \\ Jl. Ir. H. Juanda Ciputat 15419 \\ fajarsyarif@iiq.ac.id
}

\begin{abstract}
The History of Madrasa Development in Indonesia.This study is aimed to find out how the journey of madrasah's history from classical to modern times, from middle east to Indonesia, as well as the challenges for the sake of existence. To achieve these objectives, the author uses library research, using written materials that have been published as books and international journals. This study uses a historical approach and science education. The results of this study indicate that growth and development of madrasah's history in Indonesia there are two momentum determines the existence of Madrasah. First, SKB 3 minister in 1975 that became the entrance of madrasah recognition as an islamic educational institution equivalent to public shcools. Second, National Education System Law no. 2/1989 makes madrasah not only as an educational institution equivalent to public schools, more than that, madrasah is an islamic educational institution or public institution that has islamic characteristic. And well known as a PLUS public school. but on the other hand is also a challange that needs to be evidence, whether madrasah able to assume the dual status.
\end{abstract}

Keywords: Madrasah, History, Development, Islam.

Abstrak: Sejarah Perkembangan Madrasah di Indonesia. Penelitian ini bertujuan untuk mengetahui bagaimana perjalanan sejarah madrasah dari zaman klasik ke zaman modern, dari timur tengah ke Indonesia, serta tantangan demi eksistensi. Untuk mencapai tujuan ini, penulis menggunakan penelitian kepustakaan, menggunakan bahan tertulis yang telah diterbitkan sebagai buku dan jurnal internasional. Penelitian ini menggunakan pendekatan historis dan pendidikan sains. Hasil penelitian ini menunjukkan bahwa pertumbuhan dan perkembangan sejarah madrasah di Indonesia ada dua momentum menentukan keberadaan Madrasah. Pertama, menteri SKB 3 pada tahun 1975 yang menjadi pintu masuk pengakuan madrasah sebagai lembaga pendidikan Islam yang setara dengan sekolah umum. Kedua, UU Sistem Pendidikan Nasional No. 2/1989 menjadikan madrasah tidak hanya sebagai institusi pendidikan yang setara dengan sekolah umum, lebih dari itu, madrasah adalah institusi pendidikan islam atau institusi publik yang memiliki karakteristik islami. Dan dikenal sebagai sekolah negeri PLUS. tetapi di sisi lain juga merupakan tantangan yang perlu menjadi bukti, apakah madrasah mampu mengambil status rangkap.

Kata kunci: Madrasah, Sejarah, Perkembangan, Islam.

\section{Introduction}

Colin in his research stated that madrasa is a type of religious education that prioritizes the mastery of Islamic religious knowledge which then stipulates that its implementation is regulated by the Ministry of Religion. ${ }^{1}$ This is reinforced by Moland who stated in his research that Madrasas are less concerned with science, skills and technology education. ${ }^{2}$ Ambarin in his research revealed that the aim of learning in madrasas is so that students can actualize themselves optimally in people's lives. ${ }^{3}$ This was also expressed by Dina in her research that empowering and developing the skills of Madrasah graduates not only created business opportunities, but was able to minimize the economic downturn 
in Muslims. ${ }^{4}$

Madrasa $^{5}$ is one of the Islamic educational institutions that grows in society. ${ }^{6}$ In its history, Madrasa have played many important roles in this country. Aside from being an educational institution, the Madrasa was also the basis of resistance against Dutch colonialism which directly helped to educate the Indonesian people. Therefore, when this nation was independent, it has been natural for the government to show great attention to the Madrasa. However, the struggle in determining the existence of Madrasa as one of the institutions recognized by the government is full of long struggles. ${ }^{7}$ Admittedly or not, education is loaded with the influence of social and political culture. ${ }^{8}$ Therefore, education also runs dynamically following the political journey and the development of existing culture. After going through a long journey, the Madrasa can still be seen until now and we are proud that it is still an Islamic education institution that struggles to help educate the nation, although it still bears a pile of problems that become our "homework" together. Starting from the community's stigma towards the Madrasa to its status which is still overlapping with public schools in the national education system.

Along with the development of the times as indicated by advances in technology and information, it seems that madrassas will face tough challenges. This challenge seems to repeat again when the madrasa was first formed. According to Husni Rahim, there are at least two main factors which are the objectives of the establishment of madrassas in Indonesia, including: First, traditional Islamic education (surau, mosque, and pesantren) is considered to be less systematic and lacks adequate differentiation of pragmatic abilities. Secondly, the pace of development of government schools in the community tends to expand and bring the character of secularism, so it must be balanced with an Islamic education system that has a more organized and planned model and organization. ${ }^{9}$ Now these two factors have gradually begun to blow when understanding the community's needs for various capabilities to welcome the flow of technology and globalization. The grassroots community tends to send their children to public schools which are full of scientific abilities. In addition, the negative stigma given by the community to madrasas, such as: madrasas are lower-class schools, madrasas are schools that are only able to produce religious experts, madrasas are schools "clueless" (technology stutter/ lack of updates on technology), madrasas are schools that produce terrorists, ${ }^{10}$ etc. as if continuing to roll. On the other hand, madrasas are less responsive to the demands of the times and the wishes of the wider community. If all this is not responded quickly by the madrasa, then the fate of madrassas in Indonesia will deteriorate.

In this short paper, the author would like to review the madrasa in Indonesia, both in terms of history, existence, and the challenges it faces and the steps that must be taken to sustain it.

\section{Research Methods}

This short paper uses a historical approach to discuss various events by focusing on elements of place, time, object, background and figures of events. ${ }^{11}$ Through this historical approach, it can be known the origin of certain thoughts or opinions and attitudes of a figure, sect or community and the religious stereotype of a group and the attitude of a group to another. In addition, through this historical approach it can also be traced to the origin of a situation where an idea emerges from a figure, and it can be seen that an act and 
thought of a figure is actually forced by the desires and pressures that arise from himself. ${ }^{12}$

This short paper uses hermeneutic phenomenology method in interpreting and analyzing data. ${ }^{13}$ This refers to Martin Heidegger's theory which explains that phenomenological descriptions, ${ }^{14}$ are interpretations or hermeneutics, ${ }^{15}$ hermeneutic phenomenology in this study is used to understand a person's social thinking by giving interpretations of meaning contained in it. ${ }^{16}$ Interpretation is conducted to find a new understanding that madrasah not only as an educational institution equivalent to public schools, more than that, madrasah is an islamic educational institution or public institution that has islamic characteristic, as formulated by Gadamer, ${ }^{17}$ about existing values, for example values that underlie one's views about individuals, community, social interaction, social problems and others.

\section{History of Madrasa in the Frame of Islamic Education}

Madrasas are part of Islamic education. Therefore, before discussing the history of madrasa, we need to discuss the history of Islamic education first. Basically Islamic education begins with the decline of Islam itself with the sending of the Prophet Muhammad to becomeaProphet. Thevision and mission of Islamic education was then continued by his four companions as alKhulafā ar-Rāshidūn namely Abū Bakr alȘiddīq, 'Umar ibn al-Khattāb, Uthmān ibn al-'Affān, ${ }^{18}$ and 'Alī ibn Abi Tālib. ${ }^{19}$ Then it continued until the Umayyad Dynasty and the Abbasid Dynasty. ${ }^{20}$

At the time of the Prophet Muhammad, the educational institutions used in educating his people were education carried out at home (the house of al-Arqām ibn Abi al-Arqām and the house of the Prophet Muhammad himself), then at the mosque (Nabawi mosque), then at the kuttāb, ${ }^{21}$ and then șuffah. ${ }^{22}$ While education in the time of al-Khulaf ar-Rāshidūn was not much different from education in the Rasuluulah SAW period, both in aspects of subject matter (curriculum), ${ }^{23}$ educational institutions, and learning methods. This was because at that time the issue of Islam was still not complex and the Islamic territory was still limited around the Arabian Peninsula. In addition, the period between the Prophet's life and his successor was only relatively 29 years (the Prophet died in 632 AD and Ali died in $661 \mathrm{AD}$ ) so that such a short period of time was predicted that conditions during the Prophet with al-Khulafā ar-Rāshidūn were not far different. Islamic education at the time of the Prophet Muhammad SAW had curriculum referring to the Qur'an and hadith purely. So, the lessons took the form of the implementation of the Qur'anic teachings exemplified by the community from the attitude and behavior of the Prophet Muhammad. ${ }^{24}$ Although ijtihad had occurred in the time of al-Khulafā ar-Rāshidūn, it seemed that the four alKhulafā ar-Rāshidūn dominated the Islamic education curriculum.

After the end of the period of alKhulafāar-Rāshidūn, thepowerofIslamwas under the Umayyad Dynasty. During this dynasty the system of government, social institutions, law and state administration changed significantly, including the Islamic education system. Massive expansion made Islam in contact with the culture and civilization of other nations, although this dynasty focused more on Arab culture. From the unity of various nations under the auspices of Islam, there was a positive interaction that fosters the field of study of new science.

The Umayyad took about 90 years with Damascus as its capital. ${ }^{25}$ With the development of Islamic jurisdiction at that 
time made Islam far bigger so that new cultures and civilizations arose. Science of interpretations, hadiths, fiqh, language and literature, and natural sciences in this age began to grow and there were experts such as al-Hasan al-Basri, Ibn Shihab alZuhrī. and Wa danil Ibn Ata. ${ }^{26}$ The center of scientific activities were Kufa and Basrah in Iraq. ${ }^{27}$ At that time the effort to translate Greek manuscripts had begun even though it was not as large as in the afterward dynasties. ${ }^{28}$

After this weak dynasty, Islamic rule was replaced by the Abbasid Dynasty with Baghdad as its capital. History records that the golden age of Islam was in the Abbasid period, especially in the government of Harun al-Rashid, ${ }^{29}$ and his son al-Ma'mūn. ${ }^{30}$ At that time, the focus on science and philosophy peaked. Science and philosophical books were imported from Byzantium and later translated into Arabic. The translation activities of these books lasted about a century. Bait al-Hikmah, founded by al-Ma'mūn, was not only a translation center but also an academy that had a library. Among the branches of science which were prioritized in Bait alHikmah include: medicine, mathematics, optics, geography, physics, astronomy, history, and philosophy.

During the Abbasid Dynasty the world of Islamic education experienced rapid progress, both in terms of educational institutions, learning methods, educational curricula, as well as facilities and infrastructure. In addition, formal education institutions in the form of madrasas began to be established during this dynasty. Educational institutions during the Abbasid Dynasty, according to Syalabi, ${ }^{31}$ consisted of: 1 ). Mosque, as it is known that mosques are educational institutions that have existed since the Prophet Muhammad moved to Medina. But the educational process in it still continued to be developed until the days of the Abbasid Dynasty. Among the famous mosques are used for learning; The 'Umar Ibn Ash Mosque was used to study in the year 36 AH, Ahmad Bin Thulun Mosque which was used to study in $256 \mathrm{H}$., and $\mathrm{Al}$ Azhar mosque. 2). Kuttab / Maktab was a place to give low lessons or in terms of modern educational institutions can be equated with Primary Schools / Madrasah Ibtidaiyyah (MI). Teachers in maktab were called muallim. For example maktab Abu a1-Qāsim al-Balkhi (w.105 H. 723 M) in Julfa with three hundred students; 3) Palace School, which is a special educational institution held in the palace. Education here was deliberately held by court officials including the caliph who was devoted to educating the crown prince to be ready to continue his leadership. The teacher who taught at the palace school was called Mu'addib, 4) book shops, this place can be interpreted as the residence of Muslim scholars, or also called the literature salon; 5) Suffah, an educational institution since the time of the Prophet; 6) Halaqah, 7) Khārr, 8) Ribat, 9) Hospital; 10) Bookstore; 11) Library.

According to Maqdisi, as quoted by Arief, states that madrassas are Islamic educational institutions that go through three stages of transformation, starting from mosques, then khān mosques, and the latter becoming madrassas.

So, the first time the madrasa was founded as an Islamic educational institution during the Early Abbasid period. The madrassas that stood in classical times include. $^{32}$

1. Isfriyaniyah Madrasa in Naisabur was founded by Abū Ishāạ alIsfriyānī (d. 418 H./1027 AD);

2. Al-Baihaqiyah Madrasa founded by Abū ūasan 'Alī al-Bahaqiyah (d. 414 H. / 1023 AD);

3. Sa'idiyah Madrasa which was in 
the time of Sultan Mahmūd alGhaznāwi (388 H / 988 AD - 412 H / 1030 AD); and

4. The Nizāmiyah Madrasa founded by Nizāām al-Mulk in $457 \mathrm{H}$.

\section{Madrasas in Indonesia}

The history of the madrasa as one of the institutions of Islamic education in Indonesia began in the early 20th century AD. Madrasas were one of the results of Islamic reform in Indonesia. There were several reasons for the emergence of madrasas in Indonesia. According to Steenbrink, there are four factors that encouraged the emergence of renewal of Islamic education in Indonesia. ${ }^{33}$

1. Since 1900 there has been a lot of thought to return to the Qur'an and the Sunnah which has become the starting point for assessing existing religious and cultural customs.

2. The second force was the nature of national resistance to the Dutch colonial rulers.

3. The third force was the efforts of Muslims to strengthen their organizations in the social and economic fields.

4. There are a lot of people who were not satisfied with traditional education methods in studying the Qur'an and religion.

There were four main objectives that were updated. First, subject matter. The subject matter taught before the birth of renewal ideas was centered on religious studies which were concentrated in the classical books (yellow book). After the age of Islamic education renewal, the learning material was no longer just a deepening of the religious sciences but also taught general science, such as aijabar, geometry, natural sciences, chemistry, life sciences, economics, constitution, English, Dutch, etc. . Second, renewal of methods was no longer only based on sorogan, wetonan, and muzakarah methods, but has been developed into other learning methods. Third, the system is classical, students have been divided into classes based on the year of entry and duration of study. Fourth, the basic principles of education management are applied. ${ }^{34}$

Efforts to improve Islamic education in Indonesia were actually also influenced by ideas and thoughts of Middle Eastern figures such as Jamāl al-Din al-Afghānī and Muhammad 'Abduh in the 19th century. Besides that the publication of the at-Manar magazine also inspired the renewal of Islamic education in the form of modern madrasas. Their thoughts were brought by Indonesian graduates from the Middle East ${ }^{35}$ who then moved the reform of Islamic education in Indonesia, such as: Sheikh Muhammad Jamil Jambek, Haji Karim Amrullah, Haji Abdullah Ahmad, Ibrahim Musa Parabek in West Sumatra. In Java, H. Ahmad Dahlan appeared, with his Muhammadiyah movement, H. Hasan with the Persis (Persatuan Islam / Islamic Unity) movement, Haji Abdul Halim and the Ulama Union movement, K.H. Hasyim Asyary with the Nahdatul Ulama movement. ${ }^{36}$

\section{Madrasas During the Dutch Colonial Period}

One of the factors that triggered the renewal of Islamic education in Indonesia was also caused by the conditions at that time, during the administration of Governor General van Heustz. The school education system began to be held for the wider community. At first the schooling system was only for nobles (such as HIS / ELS, MULO, AMS). While for Indonesians, nobles and lowly officials were provided in first-class (HIS) and second-class (Standard School) schools aimed at producing govern- 
Tsaqufah \& Tarikh: Jurnal Kebudayaan dan Sejarah Islam

Vol. 5 №. I Januari-Juni 2020

ment, trade and company employees. ${ }^{37}$ Further development of village schools is increasingly open to the wider community or people. The presence of village schools that offer low costs, practical lessons and also promising jobs, were direct rivals of traditional educational institutions such as pesantren and surau. So that adaptation efforts were deemed necessary so that Islamic education was able to survive in competition.

With enthusiasm and supported by these conditions, several madrassas emerged in Indonesia, such as: Adabiyah Madrasa in Padang (West Sumatra). The official name is the Madrasah Adibiyah School which was founded by Sheikh Abdullah Ahmad in 1909. In 1915, the name changed to HMS (Hollandsch-Maleisch School) Adabiyah. ${ }^{38}$ In addition there were also Diniyah Madrasa founded by Zainudin Labay al-Yunusi in 1915 and the Diniyah Putri Madrasa founded by Rangkayo Ramah al-Yunusiah (Zainuddin Labay's sister) in 1923. In East Java there were Salafiyah Madrasas (which were followed by the Rejoso Jombang Islamic Boarding School), Muhammadiyah Madrasas in Yogyakarta, ${ }^{39}$ Taswiq Tullab Madrasas in Central Java, Islamic Community Unity Madrasas in West Java and Jamiat alKhayriyah Madrasas in Jakarta. ${ }^{40}$ As for Sulawesi there was Madrasa Amiriyah Islamiyah and Madrasa Ash-Shultoniyah in Kalimantan. ${ }^{41}$ Although among the madrassas there was no connection with each other, there were similarities in terms of curriculum, institutional form, management structure, and content that prioritizes religious knowledge. Asrohah distinguishes madrassas based on the curriculum content as follows. ${ }^{42}$

a. Madrasas similar to Dutch schools.

b. Madrasas whose religious curriculum and non-religious content are balanced. In other words there is a combination of religious and general subject.

c. Madrasah diniyah which is mainly stressed in the field of religious studies with little additional general subjects but very limited.

As explained above, the Dutch colonial government organized education with the aim of producing workers who could help their interests with low wages compared to bringing in workers from the West. ${ }^{43}$ In this context, madrasa education was not entirely, if not at all, in line with colonial policy. This in turn reduced their attention to madrassas with various pressures. The reason for their emphasis on madrassas was that they were concerned about the emergence of the militancy of educated Muslims. They carried out strict supervision of Islamic education institutions, such as madrasas. The form of regulation that reflected their concern was the teacher ordinance. This regulation was political in order to exert pressure so that religious education was not a trigger for a resistance to the government. This ordinance required a religious teacher to have a permit, although in the end this rule was softened, where religious teachers simply reported or notified. ${ }^{44}$

Besides that the Dutch colonial government also formed a special body tasked with overseeing religious life and Islamic education called Priesteiranden. The issuance of rules regarding religious teachers must have permission when they left was the advice of this body. More stringent regulations were issued again by the colonial government in 1925. The contents were not all people (kyai) could give recitation lessons. In 1932 more regulations were issued which allowed eradication and closure of madrassas and schools that did not have permits or 
schools that gave incompatible lessons. This regulation was called a wild school ordinance (wilde school ordonantiel).

The regulations above illustrate the tight supervision and pressure on the activities of madrasas and Islamic boarding schools in Indonesia. It was expected that in the not too distant future Islamic education would become paralyzed and ravaged, despite the fact that it had shown the opposite.

\section{Madrasas During the Japanese Occupation}

At the beginning of its presence in 1942, Japan behaved as if defending Islamic interests. The policies adopted are:

a. Placing Muslims as leaders of the Religious Affairs Office. In the Dutch era, this office was hosted by the orientalisten of the Netherlands.

b. Visiting and providing assistance to various large Islamic boarding schools.

c. Moral lessons which contents were identical with religious teachings were given in public schools.

d. Allowing the establishment of Islamic high schools in Jakarta led by KH. Wahid Hasyim, Kahar Mudzakar and Bung Hatta. ${ }^{45}$

Policies that seemed to side with the Muslims were actually in the interests of Japan itself in the context of the Greater East Asia war. Islamic and nationalist forces must be fostered to support the success of the war. When the war had raged and developed into World War II, in general the matter of education became neglected. Luckily the madrassas in the pesantren environment which were free from direct supervision of the Japanese government could still run fairly.

\section{The Old Order Government}

It was explicitly stated in the announcement of the BP KNIP (Central Indonesian National Committee of Workers) on December 22, 1945. The agency recommended that in advancing education and teaching at least the teaching in langgar and madrasa proceeded and expanded. Then on July 2, 1946, the commission known as the Indonesian Teaching Investigation Committee and chaired by $\mathrm{Ki}$ Hajar Dewantara made several proposals, among others, religious teachers were also required to be competent in general education, there must be training for religious teachers, the quality of pesantren and madrassas must be improved. This proposal was a suggestion for improving education in madrasas and pesantren.

On December 27, 1946, BP KNTP also advised the government to provide material assistance to Islamic boarding schools and madrasas. The two educational institutions are essentially a source of education and intelligence for the common people. The amount of government attention to religion and religious education led the government to establish the Ministry of Religion on January 3, 1946. In the organizational structure of the Ministry there was an education department that had the main task of dealing with matters of religious education in public schools and education in religious schools. This section is called the Department of Religious Education (JAPENDA), which carries out tasks, including:

a. Providing religious teaching in public and private schools.

b. Providing general knowledge in the madrasa, and

c. Held Religious Teacher Education (PGA) and Education of State Islamic Judges (PHIN) ${ }^{46}$

The existence of the Ministry of Religion with the above roles could be said to represent Indonesian Muslims in 
conducting Islamic education in a wider scope. This ministry which later turned into the Department of Religion was a political backing for Muslims in order for madrasah and pesantren education to receive constant attention and policy makers.

Efforts that had been made in order to strengthen the existence of madrasa as a component of national education were inclusion in Law number 4 of 1950 concerning the Principles of Education and Teaching. Article 10 paragraph (2) of the law stated that studying in religious schools that received recognition from the Minister of Religion was considered to had fulfilled the obligation to study. Madrasas that had the right to carry out learning obligations must meet the requirements of being registered with the Ministry of Religion and giving religious lessons as basic subject matter, at least 6 hours a week regularly in addition to general subjects. As a realization of the Law mandate in 1938 there was a Compulsory Education of Madrasah / Madrasah Wajib Belajar (MWB) in several places. ${ }^{47}$

A prominent picture in the history of madrasa development in the Old Order was the establishment of Religious Teacher Education (PGA) and the Education of State Islamic Judges (PHIN). Both of these institutions were intended to produce professional religious personnel, in addition to preparing personnel who were ready to develop madrasas. The presence of the PGA was a strategic guarantee for the survival of the madrasa, considering that from the PGA it was hoped that the driving force of the implementation of the madrasa would be born as well as the supplier of teacher staff for the madrasa. ${ }^{48}$

The number of madrassas up to 1965 that spread in almost all regions of Indonesia was: the amount of low level madrasa was 10,281 with 2,637,559 students; 621 first level (tsanawiyah) madrassas with 80,961 students; and 149 upper level madrasas (aliyah ) which had 27,069 students. So the total number of madrassas were 11,051 with a total of $2,745,589$ students. ${ }^{49}$

\section{The Period of the New Order Government until 1989}

The new order policy concerning madrasas was marked by continuing to develop public Islamic schools. This opportunity was based on the stipulation of Minister of Religion Number 80 in 1967 and was later terminated in 1970 based on the decision of Minister of Religion number 813/1970. At that time there were 358 public Islamic schools. In 1967, the government also began to establish State Madrasah Tsanawiyah (Islamic Junior High School). Madrasas that had the official name of Madrasah Tsanawiyah Islam Negeri, in 1970 the number had reached 182 schools spread across various regions of Indonesia. Likewise for Aliyah Madrasas which in the same year were made into State Aliyah Madrasas (Islamic Senior High School), such as the Madrasah Aliyah Al Islam Surakarta, Madrasah Aliyah in Magetan, East Java and Madrasah Aliyah Palangkin, West Sumatera. This process continued until the issuance of the decision of Minister of Religion number 213 in 1970 concerning the termination of the program..$^{50}$

Five years later, precisely in 1975 there were important events in the history of the madrasa. The Joint Decree of 3 Ministers (Surat Keputusan Bersama / SKB) was issued which contents included: the composition of madrasa learning consisted of $30 \%$ religion and $70 \%$ general, the status of madrasas was recognized to be equal to the same level of public schools, and the madrasah certificate was recognized as the same as public schools. The decree also stated that madrasa graduates could continue to higher-level schools and madrasah students might move to the same 
level of school.

As a result of the issuance of the $\mathrm{SKB}$, madrasas must make adjustments to public schools in various ways. Therefore, the Ministry of Religion which was responsible for madrasa development in 1976 compiled a madrasa curriculum which was implemented intensively in 1978. In 1984 there was another improvement in the madrasa curriculum in line with changes in the school curriculum within the Ministry of Education and Culture. ${ }^{51}$

The SKB of 3 Ministers was nothing but an effort to improve the quality of madrasah education and one of the steps in order to integrate madrasa education in the national education system. This had a positive impact, namely increasing the prestigeof themadrasaand thedevelopment of madrasa more encouraging. ${ }^{52}$

\section{Madrasas in the Age of Law Number 2/1989}

An important history in Indonesia's national education in 1989 was the birth of law number 2 concerning the National Education System. Thelaw in certain articles discuss madrasa as part of educational institutions living in this country. Madrasas in this law consisted of two types, namely madrasas which were categorized as formal education institutions and madrasas which were classified as educational institutions outside of school. Included in the first type are Madrasah Ibtidaiyah, Tsanawiyah, and Aliyah while Diniyah Madrasas are in the second category. In the context of this law MI, MTs and MA are treated as public schools that are characterized by Islam organized by the Ministry of Religion with the obligation to provide at least the same level as public schools. Madrasah Ibtidaiyah (hereinafter abbreviated as $\mathrm{MI})$ is at the level of elementary school, Madrasah Tsanawiyah is junior high school level, and Madrasah Aliyah is at the high school level.
Under these conditions, the madrasa was not too much different from public schools in terms of the content of the lesson (curriculum). Facing the facts above, the law also provided space for the Ministry of Religion and the wider community to establish religious education institutions. According to Government Regulation Number 29/1990 Article 3 (3), religious Education prioritized the preparation of students in special knowledge about related religious teachings. Furthermore, Article 4 authorized the Minister of Religion to name the Religious High School (Sekolah Menengah Keagamaan) after hearing the consideration of the Minister of Education and Culture. So in order to address this Government Regulation, the Ministry of Religion established a Special Program of Madrasah Aliyah (Madrasah Aliyah Program Khusus / MAPK), which consisted of $65 \%$ was the general field of study, the remaining $35 \%$ was in the field of religious studies. Therefore, it turned out that MAPK graduates were better than ordinary MA. ${ }^{53}$

Another reason for the establishment of MAPK which later changed to MAK (Madrasah Aliyah Keagamaan / Religious Madrasah Aliyah) was as a response to public dissatisfaction with the ordinary MA who no longer had the weight of religious studies as in previous times. The fact showed that the madrasa graduates have become immature in the general field of study, and were still imperfect in mastering the field of religious studies. MAK which curriculum was essentially intended for ulama education programs, during the time the Minister of Religion was held by Prof. Dr. Munawir Syadzali was carried out as an education intensification program through a boarding system (tutorial program) and development of Arabic and English proficiency. The composition of the curriculum from time to time gave a greater portion of religious studies: $70 \%$ 
of religious studies and $30 \%$ of general knowledge.

\section{Madrasas After the 2003 National Education System Law}

In 2003 a new National Education System Law was born. In the law number 20, the position of the madrasa as a formal Islamic education institution was recognized as the same as a school institution. The following are some of the articles that mention madrasas. Article 11 (2): Basic education in the form of Elementary School (SD) and Madrasah Ibtidaiyah (MI) or other equal forms and junior high school (SMP) and Madrasah Tsanawiyah (MTs) or other equal forms. Article 18 (3): Secondary education in the form of Senior High School (SMA), Madrasah Aliyah (MA), Vocational High School (SMK), and Vocational Madrasah Aliyah (MAK) or other equal forms. From the quote of the article, it was clear that the position of the madrasa was the same as the school. Therefore these articles were seen as a guarantee of the continuity of madrasas existence as part of national education system, ${ }^{54}$ which is increasingly legally strong. With the guarantee of the law, all people involved in the presence of madrasas should continue to make improvements to the madrasa so that they can continue to grow and develop both quantitatively and qualitatively. Especially in this reform era, it had been recommended to apply the concept of School / Madrasah-Based Management which provided leeway for managers of formal education institutions to improvise managerially without being too confined to government bureaucratic regulations. Quantitatively the growth of madrassas was increasing at the time. The results of the 2004/2005 school year data collection showed that the number of MTs nationally reached 12,054 which consisted of 1,260 were public MTs and 10,794 were private. For the Aliyah Madrasah level, there were a total of $4687 \mathrm{MA}, 634$ were public MA and 4,033 were private.

\section{Madrasas and Time Challenges}

Time shift is a part that determines changes. Changes in the times, inevitably turns out to have such a large influence on the pattern of human life that is in the round of the age itself. In the current era of globalization, this statement is evident when looking at certain aspects of human life. Science, for example, actually illustrates the existence of changes that are so rapid, and it leads to positive things, although sometimes it has a negative impact if the human being is unable to respond to these changes wisely. Globalization turns out to change the values, attitudes, and views of human life. Material values are a measure of taking attitudes and views of life. Everything new is always loved because according to some people it is a modern thing, while the old will soon be abandoned because it is considered old-fashioned and outdated.

These symptoms can be found when looking at the behavior of the lives of teenagers who in fact are still unstable mental state so it is very easy to receive influence and follow changes without first filtering. In the end they often follow the patterns of life carried by the flow of information and technology blindly without taking into account the effects it causes. The impact of the progress of science gradually leads them to the attitude of glorifying the brilliance of the ratios which in the end tore the value of idealism - humanism. The materialistic attitude that leads to the concept of hedonism will gradually erase aspects of religious ethics and erode the walls of morality and humanism. As a result, there will be a variety of demoralities such as: fights between students, sex, freedom, criminalization in various environments, 
lies, corruption, and so on. And what is even sadder is if this happens in the world of education.

In the current era of globalization, madrasas are required to be able to optimize their role as agents of Islamic and humanist moral education. Community trust in madrasas that are synonymous with Islamic morality must certainly be proven by superior output quality both in the field of science and technology, both in the community and on the world stage. Public trust in madrasas as stated in the National Education System Law Number 2/1989 which places madrasas not only as educational institutions that are equivalent to public schools, but also recognized as schools that are characterized by Islam. In other words, since the National Education System Law Number 2/1989 was implemented, madrasas can be said to be "public schools plus". This recognition should not be made a moral burden for madrassas, instead it must be a challenge that must be proven that madrasas are indeed worthy of being recognized as agents producing intelligent and moral human beings.

To be able to actualize the dual role of madrasa as a public school plus, the educational paradigm must also be changed. The dichotomy of science for today for madrassas must be abandoned. If madrassas really want to play a role in the current era of technology and information, it is necessary to recall the history of Islamic scholars, how they are able to decorate the world with science. In the history of Islamic civilization, we can examine that Muslim scientists, philosophers, scholars, and so on have a positive attitude towards non-Islamic science and technology, such as those from Greece, Persia, etc. based on a sense of optimism in accordance with Islamic teachings, the scientists and scholars at that time enthusiastically transferred science and technology from the outside which was later developed into Islamic science and technology. They are able to Islamize non-Muslim science and technology, thanks to their intelligence and high creativity which are motivated by the teachings of the Qur' an and the selectivity of the types of science and technology from the outside, so that they abandon the forms of science that endanger the faith, such as in philosophy which is hedonistic and epicuristic (which emphasizes the enjoyment of life and low desires) and the field of literature that is full of imagination and sadness (tragedy). Because Islam teaches life that is full of optimism, grace, and blessing from God rather thanindulging in lust, and an attitude of pessimism and melancholy, they develop their mindset in kalam knowledge which is philosophically analyzing eschatological and metaphysical life in which God is the final determinant.

Some science and technology experts argue that technology transfer is seen as a wrong concept of thinking, because science is a process of a number of activities in formulation, demolition, and analysis of hypotheses, axioms, laws, paradigms, and conceptualimages.So, beforetheproduction of technology products is produced, first there is theoretical science. While technology is the application. What can be transferred is the product of the scientific process, namely the technological objects. However, in my opinion, this science is the basis of technological development. In Islam, science has been identified by al-Razi to be 60 species, which eventually became the basis of the development of science and technology in the West since the centuries of Aufklarung (renaissance) through the process of transfer. Through the transfer of modern science and technology, Islamic education programs must open themselves to information about the development of science and technology as broad as possible, 
Tsaqufah \& Tarikh: Jurnal Kebudayaan dan Sejarah Islam

Vol. 5 No. I Januari-Juni 2020

along with the accommodative character of the teachings of Islam which are șälih li kulli zaman wa makān (in accordance with each era and place).

In the end the strategy of Islamic education in anticipating the progress of modern science and technology lies in the ability to configure Islamic value systems that accommodate the aspirations of Muslims to race in the science and technology field on the one hand, and on the other hand creative and psychologically pedagogical abilities to transfer modern science and technology itself. This is the minimum program of Islamic education that we need to plan and implement now.

\section{Conclusion}

In the history of madrasa growth in Indonesia, there are two momentum that really determine the existence of madrassas; first, the 1975 Ministerial Joint Decree which became the entrance to the recognition of madrasas as Islamic educational institutions that are equivalent to public schools; second, the National Education System Law Number 2/1989 which made madrasas not only as educational institutions equivalent to public schools, but also recognized as public schools characterized by Islam. In other words, madrasas can be said to be "public school plus".

It seems that this recognition and equality is still being tested at this time, is the management of madrasa capable of carrying out multiple tasks, as a public school as well as an Islamic education institution? Along with the challenges of the times, the madrasas should rise and improve.
${ }^{1}$ Penny Andrews, Colin; Bishop, "Middle Grades Transition Programs Around the Globe: Effective School Transition Programs Take A Comprehensive Approach to Ensuring Student Success in the Middle Grades," Middle School Journal 44, no. 1 (2012): 8-14.

${ }^{2}$ Naomi A Moland, "Can Multiculturalism Be Exported Dillemas of Diversity on Nigeria's Sesame Square," Chicago Journal Comparative Education Review 59, no. 1 (2015): 258-279.

${ }^{3}$ Ambarin Mooznah Auleear Owodally, "Multilingual Language and Literacy Practices and Social Identities in Sunni Madrassahs in Mauritius: A Case Study," Reading Research Quarterly 46, no. 2 (2011): 134-155.

${ }^{4}$ Dina Elshurafa, "Islamic Capitalism An Imminent Reality or a Hopeful Possibility for Islamic Finance," Arab Law Quarterly 26, no. 3 (2012): 339-360.

${ }^{5}$ Madrasas come from Arabic words: darasa which means learning; related to the word dars which means lesson. Madrasas are words that indicate places (ism makān) which means a place of study, or school. But then a different understanding between madrasas and schools developed. If so far the school has been connoted as an educational institution that teaches general knowledge and is secular in character, the madrasa is connoted as an educational institution that teaches Islamic knowledge and produces religious experts. See FarishA. Noor, Behind the Walls: Re-Appraising the Role and Importance of Madrasas in the World Today, in The Madrasa in Asia: Political Activism and Trasnational Linkages (Amsterdam: Amsterdam University Press, 2008), 9; Atho Mudzhar, "Religious Education an Politics in Indonesia: A Preliminary Study of Islamic Education and Politics, 1996-1979" 
Fajar Syarif

The Histary Uf Madrasa Development In Indonesia

(University of Queensland, 1981), 36.

${ }^{6}$ Husni Rahim, Madrasah Dalam Politik

Pendidikan Di Indonesia (Jakarta: Logos

Wacana Ilmu, 2005), 1.

${ }^{7}$ Political events and struggles for the madrasa were clearly seen when reviewing the proposals of Muhammadiyah leaders such as Lukman Harun (as the Deputy of the Muhammadiyah Central Leader), HS. Prodjokusumo, Drs. H. Sutrisno Makhdam, and others to the government to revise the 1989 PN Bill. In the bill there were several issues that must be considered by the government before the bill was passed into law. The problem lies in the first part, the words "faith" are not listed in the RUU PN Article 4 concerning the National Education Goals, while in the 1988 GBHN it was stated: 'National Education based on Pancasila aims to improve the quality of Indonesian people, namely people who believe and fear God, the One who is virtuous, personable, disciplined, ...". Secondly there is no clear list of Religious Education in the PN Bill for formal education from elementary school to university level. While in the GBHN religious education is clearly stated. Third, there are no religious schools such as Ibtidaiyah, Tsanawiyah, Aliyah, and IAIN, and the existence of Islamic boarding schools. While in Law No.4 of 1950 concerning the Basics of Education and Teaching, the Schools are clearly listed. Fourth, the unclear role and position of private universities. Fifth, there are too heavy sanctions for education providers if it is not in accordance with the PN Bill, for example: when accepting students based on sex, race, ethnicity, religion, economic status, and specific education units, a five-year prison sentence and a fine of 25 million rupiahs are threatened. Finally, the leaders' proposals were responded positively by the government by revising these errors. See Lukman Harun, Muhammadiyah Dan UndangUndang Pendidikan Nasional (Jakarta: Pustaka Panjimas, 1990), 12-15.

${ }^{8}$ Muhammad Zuhdi, Political and Social Influence on Religious School: A Historical
Perspective on Indonesia Islamic School Curricula (Montreal: McGill University, 2006), 24; Hasan Asri, Menyingkap Zaman Keemasan: Kajian Atas Lembaga-Lembaga Pendidikan (Bandung: Mizan, 1994), 51-52.

${ }^{9}$ Rahim, Madrasah Dalam Politik Pendidikan Di Indonesia, 15.

${ }^{10}$ The stigma of madrasa as a terrorist printer was spread by western journalists after the events of September 11, 2001 where the World Trade Center in America was destroyed by terrorists. Then it was aggravated by the Bali Bombing case (October 12, 2002) where the culprit (Mukhlas aka Ali Ghufron, et al) was proven to have a madrasa background. See Martin van Bruinessen, Traditionalist and Islamist Pesantren in Contemporary Indonesia, in The Madrasa in Asia: Political Activism and Transnational Linkages (Amsterdam: Amsterdam University Press, 2008), 234; Kautsar Talat, Degenerated Madrassas And Leadership Crisis In South Asia a Critical Study of Madrassas in Pakistan (USA: Pro Quest UMI Disertation Publishing, 2013), 30.

${ }^{11}$ Abuddin Nata, Metodologi Studi Islam (Depok: Rajawali Pers, 2000), 46.

${ }^{12}$ Imam Prayogo and Tobroni, Metodologi Penelitian Sosial Agama (Bandung: Remaja Rosdakarya, 2003), 66-67.

${ }^{13}$ Akhyar Yusuf Lubis, Filsafat Ilmu Dan Metodologi Posmodernis (Bogor: AkaDemiA, 2004), 100-146.

${ }^{14}$ Donald K Fromme, Systems of Psychotherapy: Dialectical Tensions and Integration (Hillsboro: Pacific University, 2011), 263.

${ }^{15}$ Martin Heidegger, Being and Time (New York: Harper Collins Publisher, 1962), 61-62.

${ }^{16}$ Sharan B. Marriam, Qualitative Research:

A Guidet Design and Implementation (San Francisco: Jossey-Bass Publisher, 2009), 205.

${ }^{17}$ Yusuf Lubis, Filsafat Ilmu Dan Metodologi Posmodernis, 130.

${ }^{18}$ Badri Yatim, Sejarah Peradaban Islam, 14th ed. (Jakarta: Raja Grafindo Persada, 2003), 36-45.

${ }^{19}$ Harun Nasution, Teologi Islam, Aliran- 
Aliran, Sejarah, Analisa Perbandingan, 2nd ed. (Jakarta: UI Press, 1972), 7-10.

${ }^{20}$ Yatim, Sejarah Peradaban Islam, 42 49.

${ }^{21}$ Kuttāb or maktab comes from the basic word kataba which means writing or place of writing. But in the end it has an understanding as a basic education institution. According to historical records, Kuttāb had existed since pre-Islam. It is estimated that it began to be developed by immigrants to Arab land consisting of Jews and Christians as their way of teaching the Torah and the Gospel, philosophy, Jadal (debating knowledge) and topics relating to their religion. Meanwhile, according to Hasan Fahmi, Kuttab is the longest-running Islamic education institution. Kuttāb seems to have been founded by the Arabs during the time of Abu Bakr and Umar, namely after they had conquered conquests and after they had relations with developed nations. Meanwhile Suwito said that at the beginning of the development of Islam, Kuttāb was carried out in the homes of the teachers concerned and the material taught was merely writing and reading the relevant and famous poems. At the end of the 1st century began to arise kuttāb which besides teaching reading and writing also taught the Qur' an and memorized it and taught the principles of Islamic teachings. This type of Kuttab is a transfer and teaching of the Qur'an in the mosque. Thus, the Kuttab developed into a formal basic education institution. SeeAsma Hasan Fahmi, Sejarah Dan Filsafat Pendidikan Islam (Jakarta: Bulan Bintang, n.d.), 30; Suwito and Fauzan, Sejarah Sosial Pendidikan Islam (Jakarta: Kencana, 2008), 102.

${ }^{22}$ Suffah is a space or building that is connected with a mosque. Educational institutions for learning activities during the time of the Prophet Muhammad when in Medina. 'Ubayd ibn Sāmid was appointed by the Prophet Muhammad as the teacher in Suffah. If the Prophet gets a gift from someone then immediately given to them. Because șuffah experts. because the Suffah Experts were friends of the Prophet Muhammad who had no permanent residence and financial strength. See Muhammad Amahzun, Manhaj Dakwah Rasulullah SAW, 2nd ed. (Jakarta: Qisthi Press, 2006), 183; Samsul Nizar and Zainal Efendi Hasibuan, Hadits Tarbawi; Membangun Kerangka Pendidikan Ideal Perspektif Rasulullah, 2nd ed. (Jakarta: Kalam Mulia, 2011), 23-33.

${ }^{23}$ Mahmud Yunus, Sejarah Pendidikan Islam, 6th ed. (Jakarta: Hadi Karya Agung, 1990), 40.

${ }^{24}$ Jalaluddin and Sa'id Umar, Filsafat Pendidikan Islam; Konsep Dan Perkembangan, 2nd ed. (Jakarta: Raja Grafindo Persada, 1996), 113.

${ }^{25}$ The great Khalifahs of this dynasty were Mu'āwiyah ibn Abi Sufyān (661-680 AD), 'Abd al-Mālik ibn Marwan (685-705 AD), al-Wālid ibn Abd al-Mālik (705-715 AD), 'Umar ibn' Abd al-Azīz (717-720 AD) and Hishām ibn 'Abd al-Mālik (724743 AD). It was in this dynasty that Islam expanded to Spain, North Africa, Syria, Palestine, the Arabian Peninsula, Iraq, parts of small Asia, Persia, Afghanistan, Pakistan, Rukmenia, Uzbek and Kyrgyz (in Central Asia). See Harun Nasution, Islam Ditinjau Dari Berbagai Aspeknya, 6th ed. (Jakarta: UI Press, 1986), 61-62.

${ }^{26}$ SuwitoandFauzan, Sejarah Pemikiran Para Tokoh Pendidikan, 1st ed. (Bandung: Angkasa, 2003), 6-8.

${ }^{27}$ Nasution, Islam Ditinjau Dari Berbagai Aspeknya, 63.

${ }^{28}$ Translation in the Umayyad era was not yet a movement, but it was still individual. The translation of Greek manuscripts was pioneered by one of the sons of Umayyad Dynasty Caliph, Khalid Ibn Yazid (84 H / 704 AD). Through his association with court doctors, Khalid finally became interested in Nestorian Christian astronomy. He commissioned Stephen, a Naoplatonic Alexandrian 
scientist to translate various astronomical / astrological works from Greek and Syriac into Arabic. Then he was interested in studying chemistry and possible methods of being able to convert metals into more valuable metals. See Armai Arief, Sejarah Pertumbuhan Dan Perkembangan LembagaLembaga Pendidikan Islam Klasik (Bandung: Angkasa, 2005), 183.

${ }^{29} \mathrm{His}$ full name is Harun al-Rashid ibn al-Mahdi ibn Abī Ja'far al-Mansur. He was born in Ray in February 145 H / 763 AD. He was the fifth leading Caliph of the Abasiy Dynasty. He was famous for his manhood and also a poet. In his reign the Abbasids reached a peak of glory in the fields of economy, trade, territory, politics, science, and Islamic civilization. He received much education from Yahyyā Ibn Khālid (805 AD) a minister during his father's reign from the Barmak family, so Harūn al-Rashīd grew up as a smart and educated and honorable person. Since his involvement in government at a young age (23 years old) and during his time as caliph, Harun al-Rashīd developed close relations with scholars, lawyers, judges, reciters, writers and artists. He often invited experts to the palace to discuss the problems at hand. He was very respectful of science and placed scholars in a noble place. See Editorial Board, Ensiklopedi Islam, 3rd ed. (Jakarta: Ichtiar Baru van Hoeve, 1994), 87.

${ }^{30} \mathrm{His}$ full name is Abdullah Abū al'Abbās al-Ma' mūn ibn Harūn al-Rashīd, he was born in 15 Rabiul Awal in $170 \mathrm{AH} /$ $786 \mathrm{AD}$, to coincide with the death of his grandfather, Musa al-Hadi, also coinciding his father was appointed caliph . AlMakmun was known as a young genius. At the age of 5 years he received religious education and reading the Qur' an under the guidance of Kasa'î and Yazìdī. In addition to studying the Qur'an he also studied the hadith from Imam Malik in Medina with his Muwatto book, he was also skilled in State science, law, fiqh, philosophy, astronomy and other sciences. Al-Makmūn was the most famous caliph in the history of the Abbasid dynasty. Aside from being a brave warrior, he was also a wise ruler. He was a person who was passionate about work, wise, forgiving, fair, intelligent, free in thinking, and tolerant. His reign marked a tremendous progress in Islamic history. For more than 21 years of his leadership, he was able to leave a legacy of valuable Islamic intellectual progress. Progress covers aspects of science, such as astronomy, mathematics, medicine, and philosophy. Starting from the principle that the progress and prosperity of the people was very dependent on the progress of education and civilization; then he made it happen by establishing various educational institutions ranging from elementary level to higher education institutions. See Muhtifah, "Konsep Dasar Multikultural Di Institusi Pendidikan Islam Zaman AlMa'mun," in Sejarah Pendidikan Islam, ed. Suwito and Fauzan, 2nd ed. (Jakarta: Kencana, 2008), 30.

${ }^{31}$ Ahmad Syalabi, Sejarah Pendidikan Islam (Jakarta: Bulan Bintang, 1973), 234.

${ }^{32}$ Arief, Sejarah Pertumbuhan Dan Perkembangan Lembaga-Lembaga Pendidikan Islam Klasik, 60-61.

${ }^{33}$ Karel A. Steenbrink, Pesantren Madrasah Sekolah (Jakarta: LP3Es, 1986), 46-47.

${ }^{34}$ Haidar Putra Daulay, Pendidikan Islam Dalam Sistem Pendidikan Nasional Di Indonesia, 2nd ed. (Jakarta: Kencana, 2007), 7-8.

${ }^{35}$ In the 1920s at al-Azhar University alone there were 200 students from Indonesia.

${ }^{36}$ Mustafa Kamal Pasha and Ahmad Adaby Darban, Muhammadiyah Sebagai Gerakan Islam, 2nd ed. (Yogyakarta: Pustaka SM, 2009), 76; Daulay, Pendidikan Islam Dalam Sistem Pendidikan Nasional Di 
Indonesia, 47.

${ }^{37}$ Rahim, Madrasah Dalam Politik Pendidikan Di Indonesia, 10.

${ }^{38}$ This madrasa was considered the first madrasa in Minangkabau that included secular (non-religious) and classy subjects. In 1916 this school had 180 students and eight of them were female students with seven teachers, two of them from Europe.

${ }^{39}$ The evidence of Muhammadiyah's seriousness in participating in educating the nation (mostly from the lower middle class) was to establish two models of educational institutions: traditional madrassas and secular schools. Curriculum content that included general subjects and added focussing subjects made Muhammadiyah schools highly desirable. In 1938 there were 466 Muhammadiyah schools (216 village schools, 166 HIS, and the rest were MULO and AMS) with teachers trained in Solo, Yogyakarta and Batavia.

${ }^{40}$ This organization was formed in 1905 by groups of Arab descent (mostly habaib / sayyid or descendants of the Prophet Muhammad). This organization formed a madrasa that included Indonesian and English subjects as compulsory subjects. See Lee Kam Hing, Education and Politics in Indonesia 19451965 (Kuala Lumpur: University of Malaya Press, 1995), 11-14.

${ }^{41}$ Rahim, Madrasah Dalam Politik Pendidikan Di Indonesia, 112-115; Nurcholish Madjid, Bilik-Bilik Pesantren; Sebuah Potret Perjalanan, 1st ed. (Jakarta: Paramadina, 1997), xiv-xv.

${ }^{42}$ Hanun Asrohah, Sejarah Pendidikan Islam (Jakarta: Logos Wacana Ilmu, 2001), 193.

${ }^{43}$ Zuhairini, Sejarah Pendidikan Islam (Jakarta: Bumi Aksara, 2004), 146; Muhammad Sirozi, Politik Kebijakan Pendidikan Di Indonesia: Peran Tokoh-Tokoh Islam Dalam Penyusunan UU No.2/1989 (Jakarta: INIS, 2004), 20; Deliar Noer, Ideologi Politik Dan
Pembangunan (Jakarta: Yayasan Perkhidmatan, 1983), 86.

${ }^{44}$ Hing, Education and Politics in Indonesia 1945-1965, 15; Maksum, Madrasah, Sejarah Perkembangannya (Jakarta: Logos Wacana Ilmu, 2001), 115.

${ }^{45}$ Zuhairini, Sej. Pendidik. Islam, 151152.

${ }^{46}$ Hing, Education and Politics in Indonesia 1945-1965, 23, 47.

${ }^{47}$ Asrohah, Sej. Pendidik. Islam, 195; Zuhdi, Political and Social Influence on Religious School: A Historical Perspective on Indonesia Islamic School Curricula, 66.

${ }^{48}$ Maksum, Madrasah, Sejarah Perkembangannya, 124.

${ }^{49}$ Hing,EducationandPoliticsinIndonesia 1945-1965, 105; Compared with Maksum, Madrasah, Sejarah Perkembangannya, 126.

${ }^{50}$ Husni Rahim, Arah Baru Pendidikan Islam Di Indonesia (Jakarta: Logos Wacana Ilmu, 2001), 55.

${ }^{51}$ Muzayin Arifin, Kapita Selekta Pendidikan Islam (Jakarta: Bumi Aksara, 2011), 26, 221-225.

${ }^{52}$ Robert W. Henfer, Islamic School, Social Movements, and Democracy in Indonesia in Making Modern Muslims: The Politics of Islamic Education in Southest Asia (Honolulu: University of Hawai Press, 2009), 66.

${ }^{53}$ Rahim, Madrasah Dalam Politik Pendidikan Di Indonesia, 21-22.

${ }^{54}$ Amin Haedari, Transformasi Pesantren: Pengembangan Aspek Pendidikan, Kegamaan Dan Sosial (Jakarta: LekDis Media Nusantara, 2006), 59.

\section{Reference}

Amahzun, Muhammad. Manhaj Dakwah Rasulullah SAW. 2nd ed. Jakarta: Qisthi Press, 2006.

Andrews, Colin; Bishop, Penny. "Middle Grades Transition Programs Around the Globe: Effective School Transition Programs Take A Comprehensive Approach to Ensuring Student Success in the Middle Grades." Middle School 
Journal 44, no. 1 (2012): 8-14.

Arief, Armai. Sejarah Pertumbuhan Dan Perkembangan Lembaga-Lembaga Pendidikan Islam Klasik. Bandung: Angkasa, 2005.

Arifin, Muzayin. Kapita Selekta Pendidikan Islam. Jakarta: Bumi Aksara, 2011.

Asri, Hasan. Menyingkap Zaman Keemasan: Kajian Atas Lembaga-Lembaga Pendidikan. Bandung: Mizan, 1994.

Asrohah, Hanun. Sejarah Pendidikan Islam. Jakarta: Logos Wacana Ilmu, 2001.

B. Marriam, Sharan. Qualitative Research: A Guidet Design and Implementation. San Francisco: Jossey-Bass Publisher, 2009.

Board, Editorial. Ensiklopedi Islam. 3rd ed. Jakarta: Ichtiar Baru van Hoeve, 1994.

Bruinessen, Martinvan. Traditionalistand Islamist Pesantren in Contemporary Indonesia, in The Madrasa in Asia: Political Activism and Transnational Linkages. Amsterdam: Amsterdam University Press, 2008.

Daulay, Haidar Putra. Pendidikan Islam Dalam Sistem Pendidikan Nasional Di Indonesia. 2nd ed. Jakarta: Kencana, 2007.

Elshurafa, Dina. "Islamic Capitalism An Imminent Reality or a Hopeful Possibility for Islamic Finance." Arab Law Quarterly 26, no. 3 (2012): 339-360.

Fahmi, Asma Hasan. Sejarah Dan Filsafat Pendidikan Islam. Jakarta: Bulan Bintang, n.d.

Haedari, Amin. Transformasi Pesantren: Pengembangan Aspek Pendidikan, Kegamaan Dan Sosial. Jakarta: LekDis Media Nusantara, 2006.

Harun, Lukman. Muhammadiyah Dan Undang-Undang Pendidikan Nasional. Jakarta: Pustaka Panjimas, 1990.

Heidegger, Martin. Being and Time. New York: Harper Collins Publisher, 1962.

Henfer, Robert W. Islamic School, Social Movements, and Democracy in Indonesia in Making Modern Muslims: The Politics of Islamic Education in Southest Asia. Honolulu: University of Hawai Press, 2009.

Hing, Lee Kam. Education and Politics in Indonesia 1945-1965. Kuala Lumpur:
University of Malaya Press, 1995.

Jalaluddin, and Sa'id Umar. Filsafat Pendidikan Islam; Konsep Dan Perkembangan. 2nd ed. Jakarta: Raja Grafindo Persada, 1996.

K Fromme, Donald. Systems of Psychotherapy: Dialectical Tensions and Integration. Hillsboro: Pacific University, 2011.

Madjid, Nurcholish. Bilik-Bilik Pesantren; Sebuah Potret Perjalanan. 1st ed. Jakarta: Paramadina, 1997.

Maksum. Madrasah, Sejarah Perkembangannya. Jakarta: Logos Wacana Ilmu, 2001.

Moland, Naomi A. "Can Multiculturalism Be Exported Dillemas of Diversity on Nigeria's Sesame Square." Chicago Journal Comparative Education Review 59, no. 1 (2015): 258-279.

Mudzhar, Atho. "Religious Education an Politics in Indonesia: A Preliminary Study of Islamic Education and Politics, 1996-1979." University of Queensland, 1981.

Muhtifah. "Konsep Dasar Multikultural Di Institusi Pendidikan Islam Zaman AlMa'mun." In Sejarah Pendidikan Islam, edited by Suwito and Fauzan. 2nd ed. Jakarta: Kencana, 2008.

Nasution, Harun. Islam Ditinjau Dari Berbagai Aspeknya. 6th ed. Jakarta: UI Press, 1986.

—. Teologi Islam, Aliran-Aliran, Sejarah, Analisa Perbandingan. 2nd ed. Jakarta: UI Press, 1972.

Nata, Abuddin. Metodologi Studi Islam. Depok: Rajawali Pers, 2000.

Nizar, Samsul, and Zainal Efendi Hasibuan. Hadits Tarbawi; Membangun Kerangka Pendidikan Ideal Perspektif Rasulullah. 2nd ed. Jakarta: Kalam Mulia, 2011.

Noer, Deliar. Ideologi Politik Dan Pembangunan. Jakarta: Yayasan Perkhidmatan, 1983.

Noor, Farish A. Behind the Walls: Re-Appraising the Role and Importance of Madrasas in the World Today, in The Madrasa 
in Asia: Political Activism and Trasnational Linkages. Amsterdam: Amsterdam University Press, 2008.

Owodally, Ambarin Mooznah Auleear. "Multilingual Language and Literacy Practices and Social Identities in Sunni Madrassahs in Mauritius: A Case Study." Reading Research Quarterly 46, no. 2 (2011): 134-155.

Pasha, Mustafa Kamal, and Ahmad Adaby Darban. Muhammadiyah Sebagai Gerakan Islam. 2nd ed. Yogyakarta: Pustaka SM, 2009.

Prayogo, Imam, and Tobroni. Metodologi Penelitian Sosial Agama. Bandung: Remaja Rosdakarya, 2003.

Rahim, Husni. Arah Baru Pendidikan Islam Di Indonesia. Jakarta: Logos Wacana Ilmu, 2001.

- - . Madrasah Dalam Politik Pendidikan Di Indonesia. Jakarta: Logos Wacana Ilmu, 2005.

Sirozi, Muhammad. Politik Kebijakan Pendidikan Di Indonesia: Peran Tokoh-Tokoh Islam Dalam Penyusunan UU No.2/1989. Jakarta: INIS, 2004.

Steenbrink, Karel A. Pesantren Madrasah Sekolah. Jakarta: LP3Es, 1986.
Suwito, and Fauzan. Sejarah Pemikiran Para Tokoh Pendidikan. 1st ed. Bandung: Angkasa, 2003.

- - - . Sejarah Sosial Pendidikan Islam.

Jakarta: Kencana, 2008.

Syalabi, Ahmad. Sejarah Pendidikan Islam. Jakarta: Bulan Bintang, 1973.

Talat, Kautsar. Degenerated Madrassas And Leadership Crisis In South Asia a Critical Study of Madrassas in Pakistan. USA: Pro Quest UMI Disertation Publishing, 2013.

Yatim, Badri. Sejarah Peradaban Islam. 14th ed. Jakarta: Raja Grafindo Persada, 2003.

Yunus, Mahmud. Sejarah Pendidikan Islam. 6th ed. Jakarta: Hadi Karya Agung, 1990.

Yusuf Lubis, Akhyar. Filsafat Ilmu Dan Metodologi Posmodernis. Bogor: AkaDemiA, 2004.

Zuhairini. Sejarah Pendidikan Islam. Jakarta: Bumi Aksara, 2004.

Zuhdi, Muhammad.Political and Social Influence on Religious School: A Historical Perspective on Indonesia Islamic School Curricula. Montreal: McGill University, 2006. 